\title{
Skin Basal Cell Carcinoma
}

National Cancer Institute

\section{Source}

National Cancer Institute. Skin Basal Cell Carcinoma. NCI Thesaurus. Code C2921.

The most frequently seen skin cancer. It arises from basal cells of the epidermis and pilosebaceous units. Clinically it is divided into the following types: nodular, ulcerative, superficial, multicentric, erythematous, and sclerosing or morphea-like. More than 95\% of these carcinomas occur in patients over 40. They develop on hair-bearing skin, most commonly on sun-exposed areas. Approximately $85 \%$ are found on the head and neck and the remaining $15 \%$ on the trunk and extremities. Basal cell carcinoma usually grows in a slow and indolent fashion. However, if untreated, the tumor may invade the subcutaneous fat, skeletal muscle and bone. Distant metastases are rare. Excision, curettage and irradiation cure most basal cell carcinomas. 